\title{
Application of modern agronomic and biotechnological strategies to valorise worldwide globe artichoke (Cynara cardunculus L.) potential - an analytical overview
}

\author{
Aneta Grabowska, ${ }^{1}$ Gianluca Caruso, ${ }^{2}$ Ali Mehrafarin, ${ }^{3}$ Andrzej Kalisz, ${ }^{1}$ Robert Gruszecki, ${ }^{4}$ \\ Edward Kunicki, ${ }^{1}$ Agnieszka Sękara ${ }^{1}$ \\ ${ }^{1}$ Department of Vegetable and Medicinal Plants, Faculty of Biotechnology and Horticulture, University of \\ Agriculture in Krakow, Poland; ${ }^{2}$ Department of Agricultural Sciences, University of Naples Federico II, \\ Italy; ${ }^{3}$ Medicinal Plants Research Centre, Institute of Medicinal Plants, ACECR, Karaj, Iran; ${ }^{4}$ Department \\ of Vegetable Crops and Medicinal Plants, University of Life Sciences in Lublin, Poland
}

\begin{abstract}
The globe artichoke [Cynara cardunculus L. var. scolymus (L.) Fiori], an ancient vegetable originated in the Mediterranean Basin, is currently cultivated in many regions of the world under a perennial cycle or as an annual crop, with the first method being more widespread globally. The growing importance of globe artichoke as modern functional food as well as a source of pharmaceuticals has raised new issues that all producers have to face; hence the necessity of contemporaneous development of new centres of production and new technologies application in traditional regions of growing which can complement the global market. This review is focused on development of globe artichoke technology of production in recent several years which meet the diversified requirements of global and local markets. We considered the recent literature to highlight specific applications of modern farming practices and plant breeding along with genetic variation to globe artichoke production system as well as to postharvest management in order to enhance the value added of this commodity. The latter targets are mainly addressed to particular regions of the world and they are based on farmers knowledge,
\end{abstract}

Correspondence: Aneta Grabowska, Department of Vegetable and Medicinal Plants, Faculty of Biotechnology and Horticulture, University of Agriculture in Krakow, Al. 29 Listopada 54, 31-425 Krakow, Poland. E-mail: aneta.grabowska@urk.edu.pl

Key words: Cynara cardunculus var. scolymus (L.) Fiori; market; quality; regionalisation; technologies.

Acknowledgements: this research was financed by the Ministry of Science and Higher Education of the Republic of Poland.

Received for publication: 15 March 2018

Revision received: 13 July 2018.

Accepted for publication: 24 July 2018.

CCopyright A. Grabowska et al., 2018

Licensee PAGEPress, Italy

Italian Journal of Agronomy 2018; 13:1252

doi:10.4081/ija.2018.1252

This article is distributed under the terms of the Creative Commons Attribution Noncommercial License (by-nc 4.0) which permits any noncommercial use, distribution, and reproduction in any medium, provided the original author(s) and source are credited. equipment, scale and methods of production, processing, final market. Our reports are focused on sustainable and environmentally friendly methods which can improve the profitability of production as well as product's quality and quantity traits. We discussed the balanced mineral application which can precisely affect the yield chemical composition, attractiveness and shelf life of globe artichoke heads as well as create the opportunities to attain standardised by-products, valuable on the market of health and convenient food. Further topics were developed, such as introduction of seed propagation, intercropping, grafting, flowering induction, postharvest treatments as linked to different regions and conditions of production. Precise selection of modern management practices was recognised as a main goal to fulfil the requirements of local and global market for fresh, processed and new potential globe artichoke products.

\section{Introduction}

The globe artichoke originates in the Mediterranean Basin, where it was most likely introduced as a crop in about the first century AD (Sonnante et al., 2007). The Mediterranean Basin remains the main globe artichoke growing region today. Italy (coastal plains of the southern regions Sicily, Apulia, Sardinia and Campania) is the world leader in globe artichoke production, while Spain is the biggest exporter and France - importer of fresh and preserved crop (Bianco, 2005; Lombardo et al., 2017b). Outside of Southern Europe and North Africa, the plant is cultivated in China, the USA (California), Argentina, Chile, Peru and Brazil, although the scale of production is not reflected by the yield. Different timing and methods of production can achieve high yields in countries where globe artichoke has not long tradition of production, like Peru, Argentine or Iran (Macua, 2007). The production value of globe artichoke is usually higher than that of any common vegetables. Therefore, commercial production could be successfully established in many regions with relevant environmental conditions, to provide new market opportunities for regional agricultural economies (Shinohara et al., 2011). In the latest review (Sękara et al., 2015) we focused on benefits development of globe artichoke production in Central Europe countries, including ethnobotanical, genetical, biochemical, and technological aspects. Present review is focused on application of new technologies for globe artichoke production with a view to meeting the changing market requirements both, in regional and global scale. In developed countries, there is a match of production 
methods to market demands focused on environmentally friendly techniques and healthy products with high level of bioactive compounds. Consumers are increasingly interested in eco-friendly food products from sustainable cropping systems characterised by low input and reduce chemical consumption with agro-ecology and the use of bio-stimulants. The implementation of micro-propagation systems, grafting, introduction of hybrid cultivars in annual cycle are commonly applied in developed countries, where there are nursery techniques and technological equipment. In developing countries the main goal of growers is to improve the profitability of production, and vegetative propagation is still the most widely used technique. The globe artichoke is a perennial plant belonging to the Asteraceae family. Morphology and physiology of this species provide a good adaptation to hot and arid Mediterranean environment (Sonnante et al., 2007), as well as a related cardoon, which can be cultivated in similar areas as a source of cellulose obtained from the stems, oil and protein from the achenes and inulin from roots (Ottaiano et al., 2017). According to Mauro et al. (2015) Cynara cardunculus L. genotypes are valuable source of renewable energy under low costs in term of soil management. The edible part of the globe artichoke is the inflorescence - flower head forming at the top of the main stem and on the lateral shoots, composed of involucral bracts surrounding a fleshy base known as the heart, a natural source of minerals, fibre, inulin and polyphenols with very little fat content. According to Lutz et al. (2011) cooking process increased the content of total phenolics especially in baby globe artichoke heads. Total phenolic contents of approximately $1.2 \%$ $(\mathrm{w} / \mathrm{w})$ on a dry matter basis revealed that globe artichoke pomace is a promising source of phenolic compounds that might be recovered and used as natural antioxidants or functional food ingredients (Lattanzio et al., 2009). The globe artichoke is popular for its pleasant bitter taste which is attributed mostly to a phytochemical called cynarin found in the green parts of the plant. Cynarin (1,3-O-dicaffeoylquinic acid) is considered one of globe artichoke's main biologically active chemicals. It occurs in the highest concentration in the leaves of the plant, which is why leaf extracts are most commonly employed in herbal medicine. Phenolic composition has medicinal value since it has antihepatotoxic, choleretic, diuretic, hypocholesterolemic and antilipidemic properties. Other documented active chemicals include flavonoids, sesquiterpene lactones, polyphenols and other caffeoylquinic acids
(Fratianni et al., 2007; Sharaf-Eldin et al., 2007; Lombardo et al., 2010). According to Lombardo et al. (2009) the highest total polyphenols content is connected with the floral stem and receptacle regardless of genotype of plant. Additionally synthesis of these compounds is more intensive in inner than in outer bracts (Pandino et al., 2012). Shinohara et al. (2011) demonstrated that total phenolic content was dependent in high degree on water content in the soil and increased crucially with its deficiency. Globe artichoke reputation as a functional food as well as a sophisticated ingredient of Italian cuisine resulted in increased economic value (Lombardo et al., 2017a). Italy is the richest reserve of globe artichoke germplasm, representing great differentiation of head morphological traits, however average consumers are willing to pay price premiums for fresh, large and green globe artichoke heads as compared with small and purple ones. Among non-chemical traits, taste, freshness, and nutrition were considered the top three factors influencing consumers' purchasing decisions (Segovia et al., 2016).

\section{Farming practices}

Globe artichoke can be cultivated in a perennial or annual cycle, with the first method being more widespread globally. To fulfil the consumers requirements, in traditional regions of globe artichoke production, farmers have to adopt high farming inputs to improve crop yield and quality. This is possible due to differentiation of methods of propagation affecting earliness and heads quality. Seedpropagated cultivars are always late because of the prolonged juvenility phase (Macua et al., 2011), but growing from seedlings allows attaining high yield even in regions with short vegetation period (Sałata et al., 2012). Flexibility in methods of propagation supplemented with a wider range of seed propagated cultivars and hybrids as well as modern growing techniques created new regions of globe artichoke production (Figure 1).

Development of new regions of globe artichoke production is not always triggered by demands of local markets. The production is often destined to processing and export, like to China, but there are some countries where domestic production meets the consumers' expectations for fresh product, for example in Poland or Latvia (Macua, 2007; Sękara et al., 2015; Zeipina et al., 2015). The potential of globe artichoke, linked to traditional culinary and medicinal use, as well as to a wide range of modern applications can bring new opportunities to growers all over the world.

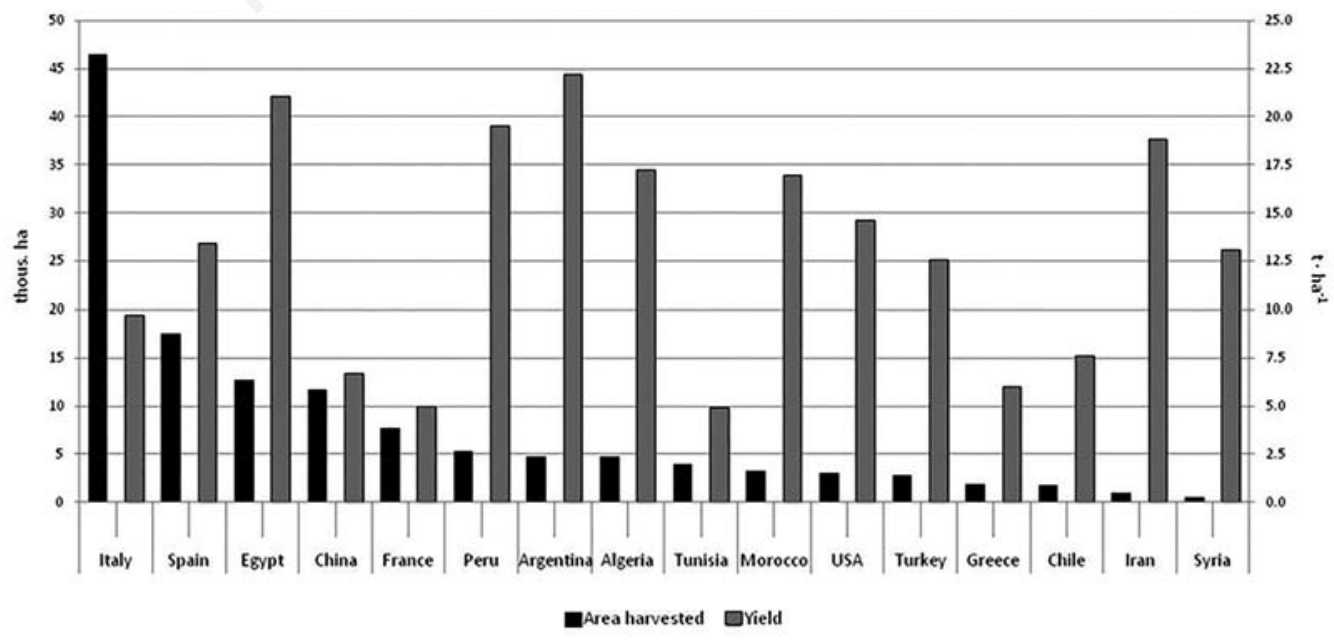

Figure 1. Yield and cultivating area of globe artichoke in the most important production regions in the world (FAO, 2017). 


\section{Methods of propagation}

\section{Vegetative propagation}

Areas where the temperature does not fall below $-10^{\circ} \mathrm{C}$ in winter (Welbaum, 1994; Halter et al., 2005) best suit cultivation requirements of globe artichoke as a perennial, commonly practiced in the Mediterranean basin (Italy, Spain, France, Greece, Turkey, Morocco and Tunisia) and in American countries with a relatively long tradition of globe artichoke growing (USA, Argentina and Chile) (Garcia et al., 2005; Macua, 2007). Vegetative propagation with the use of offshoots is the most common in practice, followed by propagation from underground shoots with apical and lateral buds, called ovoli in Italy (Morello et al., 2005) and from stumps (ceppaie). In the USA and some parts of France, the propagation material is rootstock mechanically divided into several parts, containing lateral buds from which new plants develop. A routine practice in France, Spain and Italy is to plant lateral shoots with fully-developed roots that are separated from the mother plants. At the same time, in most parts of Italy it is common to plant lateral shoots with buds that are still in the dormant state. In commercial perennial crops, depending on the rate of plant development, the rootstocks are divided and transplanted every 5-10 years (Ryder et al., 1983; Garcia et al., 2005; Smith et al., 2008).

In terms of the health status of the plants obtained in this manner, vegetative propagation is quite problematic, as the risk of transmission of pathogenic fungi, bacteria and viruses is very high. In Spain, after years of this practice, usually in combination with a lack of proper crop rotation, a drastic decline in plant health was observed due to the infection of planting material by Verticillium spp. (López et al., 2007). Intensive research is currently being conducted into biological agents that improve the phytosanitary quality of soil and effectively curb or combat this dangerous pathogen (Cirulli et al., 2010). Globe artichoke crops are also threatened by diseases induced by Pythium, Rhizoctonia and Botritis spp. (López et al., 2007). Riahi et al. (2017) managed the vegetative propagation techniques to improve plant health state as well as yield parameters with low cost methods. Authors tested summer ovoli, spring offshoots nursery's cuttings forced to pass a vegetative rest period by stopping irrigation and offshoots nursery's cuttings not forced. Forced spring offshoots nursery's cuttings produced highest yield and the heaviest primary heads, with highest total antioxidant capacity and inulin content. Proposed method of vegetative globe artichoke propagation is a sustainable and low-costs alternative to the traditional one.

\section{In vitro propagation}

The commercial importance of plant tissue culture has grown in recent years, significantly contributing to crop improvement with respect to disease elimination (Pandino et al., 2017b). Micropropagation of globe artichoke is an alternative method for production of large-scale healthy, high quality and uniform vegetative material. The use of in vitro propagation of globe artichoke, as a way of improving its rate of multiplication, was reported in several studies focused on the medium composition, growth regulators, genotypes, and the type of explants (Cadinu et al., 2004; Tavazza et al., 2004; Elia et al., 2007; Grando et al., 2011; Iapichino, 2013). In vitro propagation of globe artichoke was primary utilised for a few spring cultivars, but it was more difficult for autumn ones due to loss of earliness in a significant part of micropropagated plants (Tavazza et al., 2004). During the last years, mycorrhizal symbiosis has been used in micropropagated globe artichoke to increase survival and growth rates of plants by reducing the stresses related to transplanting (Campanelli et al., 2013; Ruta et al., 2016). Owing to the new efficient in vitro protocols, micropropagated cultivars are now widely used in European countries, where the high cost of planting material has been compensated by improved field performance complying with the consumers requirements (Castiglione et al., 2009; Bedini et al., 2012; Tavazza et al., 2016; El Boullani et al., 2017). At the same time, this strategy is quite difficult to be implemented in developing countries because of the high costs, the lack of nurseries for the in vitro plant production or inadequate timing and techniques of production (Pandino et al., 2017b; Riahi et al., 2017).

\section{Seed propagation}

For a number of years a factor limiting the widespread cultivation of annual globe artichoke crops was the lack of varieties suitable for an annual cycle that would guarantee balanced yield and quality of heads (Virdis et al., 2014). As for pathologic and economic disadvantages of the vegetative multiplication method, Italian globe artichoke breeding programs make efforts to create potential seed propagated cultivars. The breeding process encounter considerable problems with hybrids which are not Mendelian $\mathrm{F}_{1}$ with the uniformity originated from crosses between two pure lines. Globe artichoke suffers from strong inbreeding depression (Pagnotta et al., 2016). In 2007, the Italian and USA project started with the aim to create globe artichoke commercial hybrid seeds through the use of male sterility (Rey et al., 2016). Around 30 out of 500 crosses were tested for agro- and morphological traits and uniformity, some of which were registered, i.e. Romolo. The hybrid uniformity was recognised as the most important characteristic for quality and morphological traits. Among new hybrids, Opal $\mathrm{F}_{1}$ and Madrigal $F_{1}$ provided best quality heads for fresh-cut and processing industry due to high processing yield and low total polyphenol content. Tempo $\mathrm{F}_{1}$ represented a possible source of natural antioxidants for the food and pharmaceutical industry (Bonasia et al., 2010). Seedpropagated Istar $\mathrm{F}_{1}$ and Romolo $\mathrm{F}_{1}$ were evaluated by De Pascale et al. (2016) with respect to yield, mineral and polyphenolic profiles. In next investigations (Di Venere et al., 2016), using with Opera, Opal, Symphony, Madrigal, and Romolo hybrids, Opera and Opal showed the highest total polyphenol content and antioxidant activity value. De Nardi et al. (2016) showed qualitative and quantitative variability among Concert $\mathrm{F}_{1}$, Madrigal $\mathrm{F}_{1}$, Opal $\mathrm{F}_{1}$ and Symphony $F_{1}$, which allows the producer to choose the most suitable hybrid for local environmental and market conditions. Globe artichoke hybrids are characterised by more vigorous, earlier and healthier plants. These characteristics can be translated into lower input in plant protection, and more sustainable farming practices reflecting in growing hybrid popularity in all regions of globe artichoke production. Peru, Argentina, Egypt, Algeria, Iran and Syria are reported as countries with the highest productivity achieved by intensified cultivation of seed propagated hybrids, favourable climatic conditions as well as long growing season (Macua, 2007).

\section{Grafting}

Grafting could represent an important integrated strategy to manage Verticilium spp. in globe artichoke growing. Wild and cultivated cardoon accessions have been tested for resistance to Verticilium spp. in order to select the most suitable rootstocks (Ciccarese et al., 2012; Pandozy et al., 2015). Although grafting is a simple and common treatment, it requires attention, both also to synchronise the time of sowing of the two bionts to choose the proper grafting technique (Trinchera et al., 2013). Temperini et al. 
(2013) evaluated the performance of grafted globe artichoke into cultivated cardoon rootstocks, the latter increasing yield and the Verticillium spp. incidence of globe artichoke, the best grafting method was the splice grafting technique. Grafting remains a not pivotal technique, because of high costs and labour requirements. This method can be a sustainable way for cultivation of high quality genotypes or in situ maintenance and valorisation of traditional globe artichoke landraces.

\section{Cover crop and crop rotation}

Traditionally, globe artichoke cultivation in the Mediterranean Basin is based on monoculture and on use of high amounts of nitrogen fertiliser and this raises issues regarding its compatibility with sustainable agriculture. De Vos (1992) reported that in California crop rotation is not popular practice as the most plantations are perennial. Lenzi et al. (2015) studied the possibility of using globe artichoke as cash and cover crop in an organic vegetable system, yield was about $7 \mathrm{tha}^{-1}$ of heads and $50.3 \mathrm{t} \mathrm{ha}^{-1}$ of fresh biomass usable as green manure was left after harvest. The cropping system, also based on the management of soil fertility through the use of cover crops and rotations, was reported by Spanu et al. (2017). In this respect, the recovery of soil physical and chemical quality was achieved by abandoning chemical fertilisers application, including the fertility building legumes as catch- and cover crops, planning annual or biannual rotations and ploughing crop residues into soil. This is an example of successful adoption of sustainable agronomic practices in the traditional cultivation of the globe artichoke. Deligios et al. (2017) planned an innovative cropping system of long-term biannual rotation with cauliflower coupled with cover crop, which can optimise nutrient fluxes of conventionally grown globe artichoke. The application of new sustainable open-field horticultural systems, adapted to local conditions and crop rotation could be a promising way of reducing synthetic fertiliser supply and improving the productivity of globe artichoke in many regions of cultivation.

\section{Mulching}

To enhance globe artichoke yield and survival of plants mulching of field is recommended. For this purpose black plastic is the most often used material (Welbaum, 1994). According to Bratsch (2014) better yield was achieved on irrigated beds covered with black plastic mulch, where the average weight of heads was $7 \%$ higher than in the control (bare ground). Similar increase (by 9\%) of marketable yield of heads was achieved by Leskovar et al. (2013) as a result of mulching with black plastic, and marketable yield stated as early was higher by $29 \%$. In order to determine the overwintering capacity of artichoke rootstock after harvesting of heads, Rangarajan et al. (2000) mulched plants (trimmed $15 \mathrm{~cm}$ above the soil surface) with a $15 \mathrm{~cm}$ layer of straw the above-ground part of the plants, but they found that $100 \%$ of the plants were frozen during winter. Mulching can be successive applied in artichoke production, moreover the investigation of the effectiveness of biodegradable mulches can lead to environmental friendly solutions in this respect.

\section{Fertilisation}

Fertilisation is the most important factor affecting artichoke yield quality and quantity, but the precise recommendations depend on the soil and climatic conditions, cultivar, and growing technologies (Pomares et al., 2004; Feleafel, 2005; Elia and Conversa, 2007; Rincón et al., 2007; Negro et al., 2016). Lombardo et al. (2017b) showed that $\mathrm{N}$ feritilisation significantly influenced the quality and shelf life of fresh globe artichoke heads in terms of physiological, nutritional and microbiological properties. Globe artichoke is usually cultivated on a wide range of soils, often characterised by poor $\mathrm{N}$ content, and therefore $\mathrm{N}$ is considered by growers as an essential element for improving crop growth, earliness and yield. In practice, $\mathrm{N}$ fertiliser rates reach up to $700 \mathrm{~kg}$ $\mathrm{ha}^{-1}$, causing unnecessary increase of environmental and social hazard (Lombardo et al., 2017b). According to Ierna et al. (2006) and Ierna et al. (2012), the yield and quality of the globe artichoke crop, as well as balanced $\mathrm{N}$ fertilisation, are fundamentally influenced by N/P ratio. Ierna et al. (2012) reported that increasing $\mathrm{P}$ application from 50 to $150 \mathrm{~kg} \mathrm{P}_{2} \mathrm{O}_{5}$ allowed $\mathrm{N}$ application to be reduced from 450 to $300 \mathrm{~kg} \mathrm{ha}^{-1}$, concurrently increasing the productivity index. Paradiso et al. (2007) obtained the best earliness and highest yield using $200 \mathrm{~kg} \mathrm{ha}^{-1} \mathrm{~N}$ for spring globe artichoke production in Salerno region, Italy. Similarly, Lombardo et al. (2017b) identified $200 \mathrm{~kg} \mathrm{ha}^{-1} \mathrm{~N}$ as the optimal dose for obtaining minimally processed globe artichoke heads with good nutritional, sensory and microbiological quality. According to Pandino et al. (2011) a standard doses of fertilisers are as follows: $200 \mathrm{~kg} \mathrm{~N}, 80$ $\mathrm{kg} \mathrm{P}_{2} \mathrm{O}_{5}$ and $100 \mathrm{~kg} \mathrm{~K}_{2} \mathrm{O}$ per ha, when irrigation is applied.

Shinohara et al. (2011) estimated that $700 \mathrm{~mm}$ (for a bare soil system) water inputs and maximum $120 \mathrm{~kg} \mathrm{ha}^{-1} \mathrm{~N}$ appear sufficient to obtain high marketable yields, superior size and nutritional head quality of globe artichokes. Lower irrigation enhanced phenolic content but reduced marketable yield and head size. The negative correlation between $\mathrm{N}$ fertilisation and polyphenols content should be considered as a disadvantage from the side of healthy food. Simultaneously, polyphenols increase enzymatic browning phenomena, so managing the content of these compounds through balanced fertilisation can affect the external attractiveness and shelflife of globe artichoke heads.

On perennial plantations in California standard mineral rates are 168-336 kg N, 24-48 kg P and 28-93 kg K per ha each year, while in France, recommended $\mathrm{N}$ dose ranges between $150-280 \mathrm{~kg} \mathrm{ha}^{-1}$ (Ryder et al., 1983). P, K and a first dose of $\mathrm{N}$ are applied at the end of the harvesting season, after cutting down the plants. The second dose of $\mathrm{N}$ is applied as top dressing, in 2 or 3 applications together with irrigation. Of two analysed ammonium nitrate rates $(200$ and $400 \mathrm{~kg} \mathrm{ha}^{-1} ; 26 \%$, applied with $210 \mathrm{~kg}_{2} \mathrm{O}_{5}$ and $180 \mathrm{~kg} \mathrm{~K}_{2} \mathrm{O} \mathrm{ha}^{-1}$, the first was proved to be more beneficial in terms of obtaining a good quality crop for processing (Lombardo et al., 2017b). Feleafel (2005) showed that of four ammonium sulphate rates $(60,90,120$ and $\left.150 \mathrm{~kg} \mathrm{ha}^{-1}, 20.5 \% \mathrm{~N}\right)$, the last had the greatest effect on the yield (from 0.69 to $1.04 \mathrm{~kg}$ of heads per a plant). Additionally, perennial plantations are also fertilised with manure at a rate of 22 $\mathrm{t} \mathrm{ha} \mathrm{a}^{-1}$, with the main purpose of enriching the soil with organic matter (De Vos, 1992). In order to reduce the dose of nitrogen fertilisers, using of mineral-organic fertilisers is proposed (Ierna and Mauromicale, 2013).

\section{Irrigation}

Water shortages are a growing problem in many areas where globe artichokes are traditionally grown. In the Mediterranean Basin, ovoli planted in August are exposed to unfavourable water conditions associated with high temperatures and low relative humidity, which in the absence of irrigation often cause significant crop losses. Additionally deficiency of water results in physiological disorder, called black tip, that causes bracts to become dark (Smith et al., 2008). In Spain, yield and number of heads increased with increasing sprinkler irrigation up to $630 \mathrm{~mm}$ (Macua et al., 2005). In order to improve the adverse climatic conditions, mist irrigation was proposed in addition to standard crop irrigation to increase 
marketable yield on average by $28 \%$ as compared to not misted plants (Mauro et al., 2008). Shinohara et al. (2011) achieved a significant increase in yield using irrigation at $100 \%$ of evapotranspiration (ETc), as compared to $50 \%$ ETc. In some countries, adequately treated wastewater can be used for irrigation as a valid alternative to conventional water resources (Gatta et al., 2016). De Vos (1992) stated that in the major artichoke-growing regions in California, irrigation is applied 3-5 times in the amount of $80-100 \mathrm{~mm}$, supplementing the natural precipitation that usually falls between November and April in the amount of 300-500 mm. For perennial plantations irrigation starts at the beginning of new growing cycle, about 30 days after plants are cut back (Smith et al., 2008). Use of tensiometers is recommended to avoid over-irrigation which is especially dangerous on heavy soils (Bratsch, 2014). Along the Central Coast of California, USA, during the summer, the plants are sprinkled at 2-3-week intervals, or one-week intervals when a drip system is used (Shinohara et al., 2011). Drip irrigation allows for a $25 \%$ reduction in water consumption in the case of cultivation on loamy soils (Smith et al., 2008). According to López et al. (2007), water consumption is 7-8 thousand $\mathrm{m}^{3}$ per year per ha in the case of drip irrigation, and 10-11 thousand $\mathrm{m}^{3}$ using the sprinkler system. Comparing irrigation methods for globe artichoke in Tunisia, water use efficiency was 30\% higher with drip than furrow irrigation, and reflected in a higher number of heads (Mansour et al., 2005). Garcia et al. (2016) demonstrated that irrigation allows to increase the content of antioxidant compounds, principally phenols, in leaves and inflorescences of globe artichoke. Plants respond positively to increased humidity, so in many areas the crop requires irrigation, with drip irrigation being the most efficient. Additional benefit from drip irrigation in combination with precise mineral application is the reduction of fertilisers used to improve crop growth, earliness and high quality yield.

\section{Inflorescence shoots formation}

Seed propagated globe artichoke has a long vegetation period enabling autumn harvest, since September, when the market price is highest. Treating plants with gibberellic acid $\left(\mathrm{GA}_{3}\right)$ is one of the recommended methods for stimulating plants to produce inflorescences earlier. Mauromicale and Ierna (1995) reported that correct combination between sowing date and $\mathrm{GA}_{3}$ enabled uninterrupted harvesting of seed-grown Orlando $\mathrm{F}_{1}$ from end of October to mid-May. The total yield at the end of cycle was significantly higher in comparison with the most popular Italian cultivar Violetto di Sicilia. Dumičic et al. (2009) showed that double spraying of Imperial Star plants with $\mathrm{GA}_{3}$ resulted in significant increase in both main and lateral flower heads number per unit area, as well as in higher early yield. It was interesting that $45 \%$ of plants whose planting was delayed by one month with respect to the typical planting date (16 June) produced inflorescence shoots only when treated with $\mathrm{GA}_{3}$. Notably, the recommended concentration of $\mathrm{GA}_{3}$ is 20-60 $\mathrm{mg} \mathrm{L}^{-1}$, depending on the cultivar (El-Abagy et al., 2010; Bratsch, 2014). Plants respond to the correct dose of $\mathrm{GA}_{3}$ with a more erected plant habit and a light green colour of the youngest leaves (López et al., 2007). Yield can also be increased by treating plants with other chemicals, as demonstrated in studies by El-Zohiri (2009), who achieved a significant increase in the head yield per unit area by spraying the plants with salicylic and ascorbic acid in concentration of $50 \mathrm{mg} \mathrm{L}^{-1}$. Mauromicale and Ierna (1995) demonstrated that it is possible to force yielding in the winter season by applying $\mathrm{GA}_{3} 2$ or 3 times during the vegetation period for seedgrown cultivars. In Polish conditions, spraying of globe artichoke plants with $\mathrm{GA}_{3}$, in annual cultivation from seedlings, resulted in accelerating the formation of inflorescence shoots by 45 days as compared to control plants, and significantly increased the yield of heads (Sałata et al., 2013).

The floral induction by plants requires a temperature of $0-15^{\circ} \mathrm{C}$, though the process is fastest at $2-7^{\circ} \mathrm{C}$, continuing for a period of $2-$ 4 weeks (Wiebe, 1989). The vernalisation takes place naturally in winter in perennial plantations, and in spring in annual crops grown from seedlings (Dumičic et al., 2009). Planting of seedlings is therefore recommended one or two weeks after the last local spring frosts. However, that high summer temperatures can offset the vernalisation effect of plants, which may result in a small number of plants forming buds, although new varieties, such as Imperial and Emerald, appear to be resistant to devernalisation (Bratsch, 2014). The effect of low temperature on globe artichoke plants in the juvenile stage largely depends on the cultivar. Indeed, Kim et al. (2013) demonstrated that the treatment of Imperial Star seedlings with a temperature of $6^{\circ} \mathrm{C}$ initiated the formation of inflorescences in $63 \%$ of plants, while $9^{\circ} \mathrm{C}$ most efficiently initiated the generative phase in Green Globe, with $28 \%$ of plants producing inflorescences. Other authors (Rangarajan et al., 2000) recommended chilling globe artichoke seedlings before planting on a permanent site, also reporting that the initiation of the inflorescence shoot depended on the length of the cooling period and on the cultivar. Virdis et al. (2009) showed that the period of vernalisation should be longer for late, seed propagated cultivars as compared to early ones. Garcia and Cointry (2010) proposed cold treatment of seedlings at the two expanded-leaf stage as an effective method to increase globe artichoke yields. Welbaum (1994) showed that after 204 hours of cooling with temperature below $10^{\circ} \mathrm{C}$, inflorescence shoots appeared at $83 \%$ of Imperial Star plants and only $25 \%$ of Green Globe, however they appeared nearly on all plants of both cultivars only after 1356 hours. Control chilling of globe artichoke seedlings can be an environmentally friendly, low cost and simple method for controlling generative stage induction in globe artichoke, but the application of this method needs future investigations.

In the experiment conducted by Rangarajan et al. (2000) in upstate New York, Green Globe Improved and Imperial Star seedlings were treated with a temperature of $13^{\circ} \mathrm{C}$ for 19 and 6 days, with light irradiance of $300-350 \mu \mathrm{mol} \mathrm{m}^{-2} \mathrm{~s}^{-1}$ for $14 \mathrm{~h}$ a day, before being planted on a permanent site. The control plants were kept at temperature $24 / 18.5^{\circ} \mathrm{C}$ (day/night). The early yield of the chilled plants was 2.5 times higher than for the non-chilled ones, and the marketable yield was nearly 1.5 times higher. To obtain a high marketable yield, the authors recommended planting seedlings in the early days of May, when the plants are cooled naturally or cooling them before planting on a permanent site. The initiation of the inflorescence shoot depended on the length of the cooling period and on the cultivar.

Less practiced method increasing number of inflorescence shoots of globe artichoke is decapitation of the plants by removing the apex of the main stem. A study by Feleafel (2005) demonstrated that mentioned treatment, performed three months after planting of divided rootstock, resulted in the production of more lateral shoots, which contributed to a significant increase in yield per plant (8.5$14 \%$ as compared with the control).

\section{Diseases and pests}

One of the greatest threats to the globe artichoke plantation worldwide is verticillium wilt, a soil-borne disease caused by Verticillium dahliae Kleb. (Acquardo et al., 2010; Cirulli et al., 2010; Bratsch, 2014). The process of combating this disease is very complex and requires multi-faceted preventive measures, such as the use of healthy seed or planting material, the use of cultivars that are fully or partially resistant, careful preparation of the cultivation 
site through implementation of crop rotation principles, and, where possible, soil solarisation. Intensive research is currently being conducted into biological agents that improve the phytosanitary quality of soil and effectively curb or combat this dangerous pathogen (Cirulli et al., 2010). Artichoke crops are also threatened by diseases induced by Pythium, Rhizoctonia and Botritis spp. (López et al., 2007). Other diseases that may affect globe artichoke plants include Powdery mildew and wilt caused by Pythium spp., while among insects, aphids and spider mites pose the greatest threat (Bratsch, 2014). A physiological disorder manifested as darkening of the leaves of the involucral bracts may appear as well, due to calcium deficiency that increases probability of infections caused by Erwinia and Botritis spp (Francois et al., 1991).

\section{Harvesting}

Around $60 \%$ of world production of globe artichokes heads is directed to the fresh market. Generally, the standard weight of heads ranges between 200-500 g (up to $700 \mathrm{~g}$ ), but often smaller ones can be found (weighing 150-200 g). Heads are sold with a peduncle 4$6 \mathrm{~cm}$ long (Macua, 2007). Also agro-industry such as canning and freesing is greatly interested in this crop (Macua et al., 2011).

Globe artichoke heads should be harvested when they have reached maximum size but their generative development is not too advanced. A good indicator of maturity is the lower leaves of the involucral bracts, which should be slightly inclined, although this is not clearly visible in all cultivars as well as change in the colour of bracts (less bright green) (Bratsch, 2014). In California, heads are harvested regularly every 5 days, and it is estimated that more than 30 harvests are carried out in one crop over the entire season (De Vos, 1992).

Among 100 globe artichoke cultivars, there are types producing inflorescence shoots from autumn to spring and only in spring (Mauromicale et al., 2018). According to Acquadro et al. (2010) early cultivars are harvested from autumn to spring.

The variation in planting dates ensures continuity in the supply of raw material to the fresh vegetable market at local and global scale (Table 1). Spring production of globe artichoke in northern and central Italy derives from perennial crops that may last up to 68 years; for autumn-to-spring production in south regions, annual or biennial cycles are adopted, and seed-propagated cultivars are usually grown under annual cycle (Lenzi et al., 2015). Depending on the country and even the region, the head harvesting season for early varieties begins in October or November, except in Egypt (December), lasts until December, and continues from January to May in the following year. In northern France, harvesting is done between mid-May and mid-September, which complements the southern region in ensuring continuous supply of fresh material to the market throughout the year. For Tunisian growers earliness is one of the most important factors for the production, and it is directly linked to the export period (Riahi et al., 2017).

In northern France, harvest is performed between mid-May and mid-September, which complements the southern region in ensuring continuous supply of fresh heads to the market throughout the year. In this country, planting ovoli in spring allows to obtain the first harvest in August in the first year of cultivation, and in June in the second year. In Italy, harvest period lasts usually from October to May, but may start in September in case of the early varieties grown in perennial plantations. In the USA, when the plants are transplanted to the field in early spring, the first harvest can be done in the autumn of the same year. In the following year, $75-80 \%$ of plants are cut back in May to provide heads from September to May, and remaining plants are cut between August and September what allows gathered yield in the summer in the next year (Macua, 2007).
In the southern hemisphere (Argentina, Chile and Peru), the globe artichoke is usually planted between January and April and from July to December, depending on the country and region. In Argentina and Chile, harvesting of heads begins in April or May and lasts until November or December. On the Peruvian coast, the harvesting period runs from mid-July to November, while in the mountainous regions of Peru it lasts from mid-October to mid-May of the following year (Macua, 2007). Globe artichoke yield ranges from 8 to $17 \mathrm{t} \mathrm{ha}^{-1}$, depending on the cultivation method, fertiliser application rates, and cultivar, but yields above $20 \mathrm{t} \mathrm{ha}^{-1}$ have been recorded as well (Pesti et al., 2004; Shinohara et al., 2011; Ierna et al., 2012). According to Pesti et al. (2004), in case of annual cultivation in Hungary, higher yield can be achieved by early sowing - at the beginning of March. Leskovar et al. (2013) report that the mean yield of this vegetable in the USA is $14.5 \mathrm{t} \mathrm{ha}^{-1}$. In Tunisia, farmers produce cuttings by themselves, in inappropriate conditions and as a consequence the average yield of globe artichoke has never exceeded $7 \mathrm{t} \mathrm{ha}^{-1}$ during the last years (Riahi et al., 2017).

\section{Post-harvest treatment}

The ways of using the globe artichoke head depend on the scale of production and on the culinary traditions of individual countries. Globe artichokes are mainly eaten fresh, but they can also be frozen or canned (Lattanzio et al., 2009; Costabile et al., 2010). With regard to storability, the globe artichoke is a perishable vegetable and, in order to maintain the high quality of the heads during marketing, they should be cooled as soon as possible after harvest. At a temperature of $0-1{ }^{\circ} \mathrm{C}$ and relative humidity of $90-95 \%$, globe artichokes can be stored for 3 to 4 weeks (Bratsch, 2014). Precooling to a temperature below $5^{\circ} \mathrm{C}$ is practiced usually through hydro cooling, but room-cooling is possible as well (De Vos, 1992). In the USA heads are usually, graded by size and quality and packed in the field in waxed fibreboard cartoons (Smith et al., 2008). Even using pre-cooling and cold storage, globe artichoke have limited storability; in this respect, significant improvements have been achieved by using propylene films, modified atmosphere packaging, or oxalic acid (Gil-Izquierdo et al., 2001; Gil-Izquierdo et al., 2002; Alexopoulos et al., 2003; Leroy et al., 2010; Ruíz-Jiménez et al., 2014). Restuccia et al. (2014) found that pathogenic microbes could be significantly reduced through water ozonation and by ozone enrichment of the atmosphere in the storage chamber. Additionally Lombardo et al. (2015) reported that pre-treatment of globe artichokes with ozonised water and storage them for three days in cooling chambers in ozone-enriched increased in certain cultivars (e.g. Violet de Provence) the total polyphenols content and the level of antioxidant activity. High respiratory activity of globe artichoke heads requires the use of innovative techniques for reduction of respiration, postharvest pathogen infection, and microbial spoilage to extend the shelf life and preserve heads quality.

In recent years, the sector of minimally processed, convenience and pro-health food has grown rapidly in developed European countries. Globe artichoke hearts are not good raw material in this field due to high respiratory activity, and rapid biochemical and enzymatic damage. In view of particular developments of the modern market, some investigations were performed to prolong the shelf-life of ready-to-eat globe artichoke without decreasing its market performance as well as biological quality. Lombardo et al. (2017b) reported that $\mathrm{N}$ fertilisation at $200 \mathrm{~kg} \mathrm{ha}^{-1}$ is suitable for obtaining minimally processed globe artichoke heads with good nutritional, sensory and microbiological quality. Moreover, the mentioned Nfertilisation provided a higher inulin and similar ascorbic acid level in heads stored for 8 and 12 days, as compared to unfertilised control. $\mathrm{N}$ fertilisation seems to be a possible way for managing enzymatic 
browning through inhibitory effect on polyphenol synthesis. Minimally processed globe artichoke slices maintained high nutritional quality and colour parameters at least for 7 days of storage, although significant differences depended on genotype, harvest and storage time (Pandino et al., 2017a). The average shelf life of fresh ready-to-eat globe artichoke could be effectively increased to 12-15 days by vacuum impregnation techniques, modified atmosphere packaging, and low storage temperature (Garcia-Martinez et al., 2017). Sergio et al. (2016) used the innovative product semi-dried artichoke hearts for investigating storage linked properties. Authors stated that semi-dried globe artichoke, packaged in $\mathrm{MA}\left(70 \% \mathrm{~N}_{2}, 30 \%\right.$ $\mathrm{CO}_{2}$ ) could be stored for more than 30 days in refrigerated conditions.
Such by-product could have great market value due to the possibility of preserving its postharvest performance for a very long time. The investigations of pro-health methods for prolonging globe artichoke shelf-life involved also natural substances. Muratore et al. (2015) demonstrated the effectiveness of the micro- and non-perforated films to reduce microbial growth and enhance the total polyphenol content, especially for the heads treated with the anti-browning solution of ascorbic and citric acid. Oxalic acid pre-harvest treatment reduced respiration rate and increased antioxidant activity and phenols content in globe artichoke heads (Martínez-Esplá et al., 2017). The latter could be a natural and useful tool to delay the globe artichoke postharvest senescence and improve health-beneficial properties.

Table 1. Regional specificity of annual and perennial artichoke production.

\begin{tabular}{|c|c|c|c|c|}
\hline Country & Planting period & Harvesting & Cultivars & Source \\
\hline \multicolumn{5}{|c|}{ Vegetative propagation and perennial cultivation* } \\
\hline Central Italy & Spring-Autumn (ovoli) & Feb-Apr & $\begin{array}{l}\text { Romanesco, Violetto di Toscana, } \\
\text { Catanese, Violetto di Provenza }\end{array}$ & $\begin{array}{l}\text { Cardarelli et al., 2005; } \\
\text { Macua, 2007; } \\
\text { Ciancolini et al., } 2012\end{array}$ \\
\hline Southern Italy & Spring-Autumn (ovoli) & Sep-May & $\begin{array}{l}\text { Brindisino, Spinoso Sardo, } \\
\text { Violetto di Sicilia }\end{array}$ & $\begin{array}{l}\text { Cardarelli et al., 2005; } \\
\text { Macua, 2007; } \\
\text { Spanu et al., } 2017\end{array}$ \\
\hline Spain & Jun-Aug (stalks) & Oct-May & Blanca de Tudela & $\begin{array}{l}\text { Macua, 2007; } \\
\text { Lanteri and Portis, } 2008\end{array}$ \\
\hline Greece & Jun-Aug (stalks) & Oct-May & Blanca de Tudela & $\begin{array}{l}\text { Macua, 2007; } \\
\text { Lanteri and Portis, } 2008\end{array}$ \\
\hline France & Spring (ovoli) & $\begin{array}{l}1^{\text {st }} \text { year: Aug-Nov; } 2^{\text {nd. }} \\
\text { from June; } 3^{\text {rd: }} \text { from May }\end{array}$ & $\begin{array}{l}\text { Camus de Bretagne, Violet de } \\
\text { Provence, Violet de Hyères }\end{array}$ & $\begin{array}{l}\text { Macua, 2007; } \\
\text { Lanteri and Portis, } 2008\end{array}$ \\
\hline Tunisia & Aug-Sep (ovoli) & Nov-Jan & Violet de Hyères & Riahi et al., 2017 \\
\hline Turkey & Aug-Sep & Nov-Jan & $\begin{array}{l}\text { Bayrampaşa, } \\
\text { Sakiz }\end{array}$ & Macua, 2007 \\
\hline Argentina & Jan-May & May-Nov & $\begin{array}{l}\text { Blanco de San Juan, Francés Precoz, } \\
\tilde{N} a t o, \text { Precoz Italiano, }\end{array}$ & Garcia et al., 2005 \\
\hline USA & Spring & $\begin{array}{l}\text { Sep-Dec } \\
\text { Aug-Sep }\end{array}$ & Green Globe, Desert Globe & Ryder et al., 1983 \\
\hline \multicolumn{5}{|c|}{ Seed propagation } \\
\hline Southern Italy & Sept-Nov & Apr-May & $\begin{array}{l}\text { Istar } F_{1}, \text { Madrigal } F_{l} \\
\text { Opal } F_{l}, \text { Romolo } F_{l}, \text { Tempo } F_{l}\end{array}$ & $\begin{array}{l}\text { Bonasia et al., 2010; } \\
\text { De Pascale et al., 2016; } \\
\text { Rouphael et al., } 2017\end{array}$ \\
\hline Algeria & Jul-Aug & Oct-Nov & & Macua, 2007 \\
\hline Spain & Jul-Aug & Oct-Nov & & Macua, 2007 \\
\hline Greece & Jul-Aug & Oct-Nov & & Macua, 2007 \\
\hline Egypt & Aug-Oct & Dec-May & Green Globe, Imperial Star & Macua, 2007 \\
\hline Iran & Apr-May & Sept & Local ecotypes & Hosseinzadeh et al., 2013 \\
\hline Turkey & Jul-Aug & Jan & A-106, A-109, Green Globe, Opal Fl & Temirkaynak et al., 2008 \\
\hline $\begin{array}{l}\text { Central and } \\
\text { Eastern Europe }\end{array}$ & May & July-Sept & Concerto $F_{l}$, Imperial Star, Madrigal $F_{1}$ & $\begin{array}{l}\text { Pesti } \text { et al., 2004; } \\
\text { Halter } \text { et al., 2005; } \\
\text { Sałata et al., } 2012\end{array}$ \\
\hline China & Oct-Nov & March-Jun & A-106, Imperial Star, Lorca & Macua, 2007 \\
\hline Argentina & Jun & March & $\begin{array}{l}\text { A-106, Imperial Star, Lorca, } \\
\text { Madrigal } F_{l}, \text { Opal } F_{l}\end{array}$ & Macua, 2007; Pomés et al., 2016 \\
\hline USA & Jun-Aug & Nov-Apr & $\begin{array}{l}\text { Early Emerald Pro, Emerald, } \\
\text { Imperial Star, Madrigal } F_{l} \text {, } \\
\text { Opal } F_{l}, \text { Tempo } F_{l}\end{array}$ & $\begin{array}{l}\text { De Vos, 1992; } \\
\text { Schrader and Mayberry, } 1992\end{array}$ \\
\hline
\end{tabular}

*For vegetative propagation, planting period reflects the period of plantation establishment. 


\section{Conclusions}

Nowadays, globe artichoke is more and more popular and desired by consumers all over the world for its taste and pro-healthy properties. For this reason is successfully grown in many regions of the world in both hemispheres. The vegetative propagation, dominating in many countries, is problematic in terms of the health status of plants, due to risk of transmission of pathogens. To avoid this problem different approaches are proposed. One of them is using of summer ovoli and spring offshoots nursery's cutting which are considered as more sustainable and less-costs method in comparison with the traditional one. In vitro propagation can be considered as an alternative way for production of healthy, high quality and uniform vegetative material on the large scale; very efficient but also expensive and addressed to developed countries. Commercial hybrids, which can give yield within one vegetation season, are more and more popular in many countries and are the good solution for regions with severe winters, where establishing plantations cultivated for many years is impossible. Hybrid cultivars, as Concert, Madrigal, Opal, or Symphony are vigorous, early and healthy which yielding on the same level as plants propagated by the vegetative methods. Grafting of globe artichoke into cultivated cardoon rootstocks allows increasing yield and decreasing Verticillium incidence, but high costs and labour requirements mean that is not used on the massive scale.

The most important factor affecting artichoke yield quality and quantity is fertilisation, which depend on the soil and climatic conditions, cultivar, and growing technologies. Globe artichoke is usually cultivated on a wide range of soils, often characterised by poor $\mathrm{N}$ content, and therefore $\mathrm{N}$ is considered by growers as an essential element for improving crop growth, earliness and quantity of yield. Water shortages are a growing problem in many areas where artichokes are traditionally grown. Drip irrigation allows for a $25 \%$ reduction in water consumption in the case of cultivation on loamy soils. Reproductive phase induction is depended on prior vernalisation (cooling), which takes place naturally in the winter in perennial plantations, and in the spring in annual crops, grown from seedlings. The treatment with the growth regulators is practiced as well to reduce the number of non-productive plants. Harvest of globe artichoke heads should be done when they have reached maximum size but their generative development is not too advanced. The yield ranges usually from 8 to $17 \mathrm{tha}^{-1}$, depending on the cultivation method, fertiliser rates, and cultivar. With regard to storability, the globe artichoke is a perishable vegetable. In order to maintain the high quality during marketing, heads should be precooled as soon as possible after harvest (one of a routine practise is cooling in cold water to $5^{\circ} \mathrm{C}$ ). The duration of cooling process largely depends on the size of the heads. The optimum conditions which allow to store globe artichoke for 3-4 weeks are a temperature of $0-1{ }^{\circ} \mathrm{C}$ and relative humidity of $90-95 \%$. To enhance the duration of storability of globe artichoke heads, the use of propylene films, modified atmosphere packaging, or oxalic acid is recommended.

\section{References}

Acquadro A, Papanice MA, Lanteri S, Bottalico G, Portis E, Campanale A, Finetti-Sialer MM, Mascia T, Sumerano P, Gallitelli D, 2010. Production and fingerprinting of virus-free clones in a reflowering globe artichoke. Plant Cell Tiss. Organ. Cult. 100:329-37.
Alexopoulos AA, Akoumianakis KA, Passam HC, 2003. The storage of globe artichokes under modified atmospheres. J. Food Agric. Environ. 1:130-3.

Bedini L, Lucchesini M, Bertozzi F, Graifenberg A, 2012. Plant tissue cultures from four Tuscan globe artichoke cultivars. Cent. Eur. J. Biol. 7:680-9.

Bianco VV, 2005. Present situation and future potential of artichoke in the Mediterranean basin. Acta Hortic. 681:39-55.

Bonasia A, Conversa G, Lazzizera C, Gambacorta G, Elia A, 2010. Morphological and qualitative characterization of globe artichoke head from new seed-propagated cultivars. J. Sci. Food Agric. 90:2689-93.

Bratsch A, 2014. Specialty crop profile: Globe artichoke. Virginia Cooperative Extension, Virginia Tech, Virginia State University, 438-108:1-9.

Cadinu M, Repetto A, Frau A, Beneventi S, Meloni S, 2004. Influence of the explant type on the phenotypic changes in micropropagated plants of artichoke. Acta Hortic. 660:373-80.

Campanelli A, Ruta C, Tagarelli A, Morone-Fortunato I, De Mastro G, 2013. Effectiveness of mycorrhizal fungi on globe artichoke (Cynara cardunculus L. var. scolymus) micropropagation. J. Plant Interact. 9:100-6.

Cardarelli M, Rouphel Y, Saccardo F, Colla G, 2005. An innovative vegetative propagation system for large-scale production of globe artichokes transplants. Part I. Propagation system setup. HortTechnol. 15:812-6.

Castiglione V, Cavallaro V, Di Silvestro I, Barbera AC, 2009. Acclimatization of micropropagated globe artichoke (Cynara cardunculus L. subsp. scolymus (L.) Hegi) plantlets as affected by mycorrhizal inoculum, transplantation time and genotype. Acta Hortic. 812:461-6.

Ciancolini A, Rey NA, Pagnotta MA, Crino P, 2012. Characterization of Italian spring globe artichoke germplasm: morphological and molecular profiles. Euphytica 186:433-43.

Ciccarese F, Crinò P, Raccuia SA, Temperini A, 2012. Use of resistant cardoons as rootstocks for the control of Verticillium wilt in globe artichoke. Acta Hortic. 942:201-5.

Cirulli M, Bubici G, Amenduni M, Armengol J, Berbegal M, Del Mar Jiménez-Gasco M, Jiménez-Díaz RM, 2010. Verticillium wilt: a threat to artichoke production. Plant Dis. 94:1176-87.

Costabile A, Kolida S, Klinder A, Gietl E, Bäuerlein M, Frohberg C, Landschütze V, Gibson GR, 2010. A double-blind, placebocontrolled, cross-over study to establish the bifidogenic effect of a very-long-chain inulin extracted from globe artichoke (Cynara scolymus) in healthy human subjects. Br. J. Nutr. 104:1007-17.

De Nardi FS, Calvete EO, Reolon-Costa A, Costa RC, Cravero VP, Scheffer-Basso SM, Chiomento JLT, 2016. Morpho-agronomic variability of artichoke seed-propagated hybrids. Acta Hortic. 1147:69-76.

De Pascale S, Rouphael Y, Graziani G, Ritieni A, Colla G, Fiorillo A, Saccardo F, 2016. Yield, mineral and polyphenolic composition of two seed-propagated globe artichoke cultivars. Acta Hortic. 1147:83-8.

De Vos NE, 1992. Artichoke production in California. HortTechnol. 2:438-44.

Deligios PA, Tiloca MT, Sulas L, Buffa M, Caraffini S, Doro L, Sanna G, Spanu E, Spissu E, Urracci GR, Ledda L, 2017. Stable nutrient flows in sustainable and alternative cropping systems of globe artichoke. Agron. Sustain. Dev. 37:54.

Di Venere D, Pieralice M, Linsalata V, Gatto MA, Sergio L, Calabrese N, 2016. Biochemical evaluation of artichoke cultivars propagated by seed. Acta Hortic. 1147:89-94. 
Dumićic G, Ban SG, Bućan L, Borošic J, Poljak M, 2009. Effect of gibberellic acid application on growth and yield of artichoke under summer conditions. J. Food Agr. Environ. JAFE 7:620-6.

El Boullani R, Lagram K, El Mousadik A, Serghini MA, 2017. Effect of explants density and size on the in vitro proliferation and growth of separated shoots of globe artichoke (Cynara cardunculus var. scolymus L.). J. Mater. Environ. Sci. 8:2469-73.

El-Abagy HMH, Rashad El-ShM, Abdel-Mawgoud AMR, ElGradly NHM, 2010. Physiological and biochemical effects of some bioregulators on growth, productivity and quality of artichoke (Cynara scolymus L.) plant. Res. J. Agric. Biol. Sci. 6:683-90.

El-Zohiri SSM, 2009. Role of the salicylic and ascorbic acid on the control of growth, flowering and yield of globe artichoke. Ann. Agric. Sci. 47:393-402.

Elia A, Conversa G, 2007. Mineral nutrition aspects in artichoke growing. Acta Hortic. 730:239-49.

Elia A, Conversa G, Montervino C, Lotti C, 2007. Micropropagation of the early artichoke cultivar 'Violet du Provence'. Acta Hortic. 730:127-34.

FAO, 2017. Statistical Database. Available from: http://www.faostat.org/

Feleafel MN, 2005. Effects of decapitation time and nitrogen rate on vegetative growth, yield and quality characteristics of globe artichoke. J. Agric. Environ. Sci. Alex. Univ. Egypt 4:78-95.

Francois LE, Donovan TJ, Maas EV, 1991. Calcium deficiency of artichoke buds in relation to salinity. HortSci. 26:549-53.

Fratianni F, Tucci M, De Palma M, Pepe R, Nazzaro F, 2007. Polyphenolic composition in different parts of some cultivars of globe artichoke (Cynara cardunculus L. var. scolymus (L.) Fiori). Food Chem. 104:1282-6.

Garcia SM, Cointry EL, 2010. Vernalization of seed and plantlets and development of globe artichoke. Int. J. Veg. Sci. 16:184-90.

Garcia SM, Firpo IT, Cointry EL, López Anido FS, Cravero VP, 2005. Artichoke situation in Argentina. Acta Hortic. 681:195-200.

Garcia SM, Rotondo R, López Anido FS, Cointry EL, Santa Cruz P, Furlán R, Escalante AM, 2016. Influence of irrigation on the chemical compounds in leaves in vegetative and reproductive stage and bracts of globe artichoke (Cynara cardunculus var. scolymus L.). Acta Hortic. 1147:95-102.

Garcia-Martinez N, Andreo-Martinez P, Almela L, Guardiola L, Gabaldon JA, 2017. Microbiological and sensory quality of fresh ready-to-eat artichoke hearts packaged under modified atmosphere. J. Food Prot. 80:740-9.

Gatta G, Libutti A, Beneduce L, Gagliardi A, Disciglio G, Lonigro A, Tarantino E, 2016. Reuse of treated municipal wastewater for globe artichoke irrigation: Assessment of effects on morphoquantitative parameters and microbial safety of yield. Sci. Hortic. 213:55-65.

Gil-Izquierdo A, Conesa MA, Ferreres F, Gil MI, 2002. Influence of modified atmosphere packaging on quality, vitamin $\mathrm{C}$ and phenolic content of artichokes (Cynara scolymus L.). Eur. Food Res. Technol. 215:21-7.

Gil-Izquierdo A, Gil MI, Conesa MA, Ferreres F, 2001. The effect of storage temperatures on vitamin $\mathrm{C}$ and phenolics content of artichoke (Cynara scolymus L.) heads. Innov. Food Sci. Emerg. Technol. 2:199-202.

Grando MF, Augustin L, Suzin M, Calvete EO, Comin RC, Costa AR, Morlin B, Donida B, 2011. Micropropagation of globe artichoke 'Nobre-Upf', a brazilian cultivar used for industrial purpose. Acta Hortic. 923:147-54.

Halter L, Habegger R, Schnitzler WH, 2005. Field technologies for commercial production of artichoke (Cynara scolymus L.) in
Germany. Acta Hortic. 681:169-74.

Hosseinzadeh M, Shekari F, Janmohammadi M, Sabaghnia N, 2013. Effect of sowing date and foliar application of salicylic acid on forage yields and quality of globe artichoke (Cynara scolymus L.). Ann. UMCS Sect. E 68:50-9.

Iapichino G, 2013. Micropropagation of Globe Artichoke (Cynara cardunculus L. var. scolymus). pp 369-380 in Protocols for Micropropagation of Selected Economically-Important Horticultural Plants. Springer, New York, NY, USA.

Ierna A, Mauro RP, Mauromicale G, 2012. Improved yield and nutrient efficiency in two globe artichoke genotypes by balancing nitrogen and phosphorus supply. Agron. Sustain. Dev. 32:773-80.

Ierna A, Mauromicale G, 2013. Effects of organo-mineral fertilizers on yield characteristics of globe artichoke. Acta Hortic. 983:275-81.

Ierna A, Mauromicale G, Licandro P, 2006. Yield and harvest time of globe artichoke in relation to nitrogen and phosphorus fertilization. Acta Hortic. 700:115-9.

Kim ChH, Seong KCh, Ahn YK, Kim SCh, Song EY, Lim ChK, Son D, 2013. Effect of vernalizing temperature on growth and yield of globe artichoke. Protected Hort. Plant Fac. 22:209-13.

Lanteri S, Portis E, 2008. Globe artichoke and cardoon. In: J. Prohens and F. Nuez (Eds.), Handbook of Plant Breeding. Springer Science Business Media, New York, NY, USA.

Lattanzio V, Kroon PA, Linsalata V, Cardinali A, 2009. Globe artichoke: a functional food and source of nutraceutical ingredients. J. Funct. Foods 1:131-44.

Lenzi A, Baldi A, Tesi R, 2015. Artichoke (Cynara scolymus L.) as cashcover crop in an organic vegetable system. Acta Agric. Slov. 105:53-60.

Leroy G, Grongmet JF, Mabeau S, Le Corre D, Baty-Julien C, 2010. Changes ininulin and soluble sugar concentration in artichokes during storage. J. Sci. Food Agric. 90:1203-9.

Leskovar DI, Xu Ch, Agehara S, 2013. Planting configuration and plasticulture effects on growth, physiology, and yield of globe artichoke. HortSci. 48:1496-501.

Lombardo S, Pandino G, Mauro R, Mauromicale G, 2009. Variation of phenolic content in globe artichoke in relation to biological, technical and environmental factors. Ital. J. Agron. 4:181-9.

Lombardo S, Pandino G, Mauromicale G, 2017a. Minerals profile of two globe artichoke cultivars as affected by NPK fertilizer regimes. Food Res. Int. 100:95-9.

Lombardo S, Pandino G, Mauromicale G, Knödler M, Carle R, Schieber A, 2010. Influence of genotype, harvest time and plant part on polyphenolic composition of globe artichoke (Cynara cardunculus L. var. scolymus (L.) Fiori). Food Chem. 119:1175-81.

Lombardo S, Pandino G, Restuccia C, Muratore G, Licciardello F, Mauro RP, Pesce R, Mauromicale G, 2015. Effect of cultivar x ozone treatment interaction on the total polyphenols content and antioxidant activity of globe artichoke. Ital. J. Agron. 10:105-7.

Lombardo S, Restuccia C, Muratore G, Barbagallo RN, Licciardello F, Pandino G, Scifò GO, Mazzaglia A, Ragonese F, Mauromicale G, 2017b. Effect of nitrogen fertilisation on the overall quality of minimally processed globe artichoke heads. J Sci. Food Agric. 97:650-8.

López J, Gonzáles A, Vicente FE, Condés LF, Fernández JA, 2007. Artichoke production in the province of Murcia (SE Spain). Acta Hortic. 730:223-7.

Lutz M, Henríquez C, Escobar M, 2011. Chemical composition and antioxidant properties of mature and baby artichoke (Cynara scolymus L.) raw and cooked. J. Food Compost. Anal. 24:49-54.

Macua JI, 2007. New horizons for artichoke cultivation. Acta 
Hortic. 730:39-48

Macua JI, Lahoz I, Bozal JM, 2011. Evolution in seed propagated artichoke growing in cold zones of Spain. Acta Hortic. 942:331-6.

Macua JI, Lahoz I, Garnica J, 2005. The influence of irrigation water quantities on the production and quality of the 'Blanca de Tudela' artichoke. Acta Hortic. 681:257-62.

Mansour M, Mougou R, Mougou A, 2005. Effect of several modes of irrigation and fertigation on artichoke crop. Acta Hortic. 681:127-34.

Martínez-Esplá A, García-Pastor ME, Zapata PJ, Guillén F, Serrano M, Valero D, Gironés-Vilaplana A, 2017. Preharvest application of oxalic acid improves quality and phytochemical content of artichoke (Cynara scolymus L.) at harvest and during storage. Food Chem. 230:343-9.

Mauro RP, Di Nicola M, Longo AMG, Mauromicale G, 2008. The effects of mist irrigation on biological and productive behaviour of globe artichoke. Opt. Méd. Sér. A 84:41-4.

Mauro RP, Sortino O, Pesce GR, Agnello N, Lomardo S, Pandino G, Mauromicale G, 2015. Exploitability of cultivated and wild cardoon as long-term, low-input energy crops. Ital. J. Agron. $10: 44-6$

Mauromicale G, Ierna A, 1995. Effects of gibberelic acide and sowing date on harvest time and yields of grown globe artichoke (Cynara scolymus L.). Agronomie 15:527-38.

Mauromicale G, Portis E, Acquardo A, Lo Monaco A, Pesce GR, Lanteri S, 2018. An integrated model to accelerate the development of seed-propagated varieties of globe artichoke. Crop Breed. Appl. Biot. 18:72-80.

Morello N, Santoiemma G, Ierna A, Mauromicale G, 2005. Improvement of "ovoli" production in globe artichoke by removal of the epigeal part of the plant. Acta Hortic. 681:251-6.

Muratore G, Restuccia C, Licciardello F, Lombardo S, Pandino G, Mauromicale G, 2015. Effect of packaging film and antibrowning solution on quality maintenance of minimally processed globe artichoke heads. Innov. Food Sci. Emerg. Technol. 31:97-104.

Negro D, Montesano V, Sonnante G, Rubino P, De Lisi A, Sarli G, 2016. Fertilization strategies on cultivars of globe artichoke: Effects on yield and quality performance. J. Plant Nutr. 39:279-87.

Ottaiano L, Di Mola I, Impagliazzo A, Cozzolino E, Masucci F, Mori M, Fagnano M, 2017. Yields and quality of biomasses and grain in Cynara cardunculus L. grown in southern Italy, as affected by genotype and environmental conditions. Ital. J. Agron. 12:375-82.

Pagnotta MA, Rey NA, Mondini L, Aringoli R, Jordan R, Saccardo F, 2016. Assessment of artichoke hybrids under USA and Italian conditions and the hereditability of some important traits. Acta Hortic. 1147:257-64.

Pandino G, Barbagallo RN, Lombardo S, Restuccia C, Muratore G, Licciardello F, Mazzaglia A, Ricceri J, Pesce GR, Mauromicale G, 2017a. Quality traits of ready-to-use globe artichoke slices as affected by genotype, harvest time and storage time. Part I: Biochemical and physical aspects. LWT-Food Sci. Technol. 76:181-9.

Pandino G, Lombardo S, Antonino LM, Ruta C, Mauromicale G, 2017 b. In vitro micropropagation and mycorrhizal treatment influences the polyphenols content profile of globe artichoke under field conditions. Food Research International 99:385-92.

Pandino G, Lombardo S, Mauro RO, Mauromicale G, 2012. Variation in polyphenol profile and head morphology among clones of globe artichoke selected from a landrace. Sci. Hortic. 138:259-65.

Pandino G, Lombardo S, Mauromicale G, 2011. Mineral profile in globe artichoke as affected by genotype, head part and enviroment. J. Sci. Agric. 91:302-8.

Pandozy G, Trinchera A, Rinaldi S, Rea E, Saccardo F, Crinò P, 2015. Grafting of artichoke for the sustainable management of Verticillium wilt. pp 265-270 in Proc. IX-th Int. Symp. on Artichoke, Cardoon and Their Wild Relatives. ISHS: KorbeekLo, Belgium.

Paradiso R, Cuocolo B, De Pascale S, 2007. Gibberellic acid and nitrogen rate affect yield and quality of artichoke. Acta Hortic. 730:211-6.

Pesti NO, Ombódi A, Szöcs A, Kassai T, Dimény J, 2004. The effect of sowing dates and seedlings' state of advancement on the yield and bud quality of globe artichoke in Hungary. Acta Hortic. 660:423-7.

Pomares F, Baixauli C, Aguilar JM, Giner A, Tarazona F, Gómez J, Albiach R, 2004. Effects of water and nitrogen fertilization on seed-grown globe artichoke. Acta Hortic. 660:303-9.

Pomés J, Chale W, Masi MA, De Benedetto JP, Zanek CT, Martinez SB, 2016. Phenology of two hybrids of artichoke (Cynara cardunculus L.) in Junin, Buenos Aires. Acta Hortic. 1147:209-12.

Rangarajan A, Ingall BA, Zeppelin VC, 2000. Vernalization strategies to enhance production of annual globe artichoke. HortTechnol. 10:585-8

Restuccia C, Lombardo S, Pandino G, Licciardello F, Muratore G, Mauromicale G, 2014. An innovative combined water ozonisation/O3-atmosphere storage for preserving the overall quality of two globe artichoke cultivars. Innov. Food Sci. Emerg. Technol. 21:82-9.

Rey NA, Jordan R, Saccardo F, Pagnotta MA, 2016. A successful strategy to obtain artichoke hybrids. Acta Hortic. 1147:357-68.

Riahi J, Nicoletto C, Bouzaein G, Sambo P, Khalfallah KK, 2017. Effect of vegetative propagation materials on globe artichoke production in semi-arid developing countries: agronomic, marketable and qualitative traits. Agronomy 7:65.

Rincón L, Pérez A, Pellicer C, Abadia A, Sáez J, 2007. Nutrient uptake by artichoke. Acta Hortic. 730:287-92.

Rouphael Y, Colla G, Graziani G, Ritieni A, Cardarelli M, De Pascale S, 2017. Phenolic composition, antioxidant activity and mineral profile in two seed-propagated artichoke cultivars as affected by microbial inoculants and planting time. Food Chem. 234:10-9.

Ruíz-Jiménez JM, Zapata PJ, Serrano M, Valero D, MartínezRomero D, Castillo S, Guillén F, 2014. Effect of oxalic acid on quality attributes of artichokes stored at ambient temperature. Postharv. Biol. Technol. 95:60-3.

Ruta C, Tagarelli A, Vancini C, De Mastro G, 2016. Evaluation of commercial arbuscular mycorrhizal inoculants on micropropagated early globe artichoke during the acclimatization stage. Acta Hortic. 1147:369-74.

Ryder EJ, De Vos NE, Bari MA, 1983. The globe artichoke (Cynara scolymus L.) HortSci. 18:646-53.

Sałata A, Gruszecki R, Dyduch J, 2013. The effect of gibberellic acid $\mathrm{GA}_{3}$ on morphological features of artichoke (Cynara scolymus L.). Modern Phytomorphol. 4:87-90.

Sałata A, Gruszecki R, Dyduch J, 2012. Morphological and qualitative characterization of Globe artichoke (Cynara scolymus L.) cultivars 'Symphony' and 'Madrigal' on depending of the heads growth. Acta Sci. Pol. Hort. Cultus 11:67-80

Schrader WL, Mayberry KS, 1992. 'Imperial Star' artichoke. HortSci. 27:375-6.

Segovia MS, Palma MA, Leskovar DI, 2016. Factors affecting consumer preferences and willingness to pay for artichoke 
products. Acta Hortic. 1147:271-80.

Sękara A, Kalisz A, Gruszecki R, Grabowska A, Kunicki E, 2015. Globe artichoke - a vegetable, herb and ornamental of value in central Europe - A review. J. Hortic. Sci. Biotechnol. 90:365-74.

Sharaf-Eldin MA, Schnitzler WH, Nitz G, Razin AM, El-Oksh II, 2007. The effect of gibberellic acid $\left(\mathrm{GA}_{3}\right)$ on some phenolic substances in globe artichoke (Cynara cardunculus var. scolymus (L.) Fiori). Sci. Hortic. 111:326-9.

Shinohara T, Agehara S, Yoo KS, Leskovar D, 2011. Irrigation and nitrogen management of artichoke: yield, head quality and phenolic content. HortSci. 46:377-86.

Smith R, Baameur A, Bari M, Cahn M, Giraud D, Natwick E, Takele E, 2008. Artichoke production in California. University of California, Division of Agriculture and Natural Resources. Publication 7221:1-6. Available from: http://anrcatalog. ucdavis.edu/

Sonnante G, Pignone D, Hammer K, 2007. The Domestication of Artichoke and Cardoon: From Roman Times to the Genomic Age. Ann. Bot. 100:1095-100.

Spanu E, Deligios PA, Azara E, Delogu G, Ledda L, 2017. Effects of alternative cropping systems on globe artichoke qualitative traits. J. Sci. Food Agric. 98:1079-87.

Tavazza R, Papacchioli V, Ancora G, 2004. An improved medium for in vitro propagation of globe artichoke (Cynara scolymus L.) cv. Acta Hortic. 660:91-7.

Tavazza R, Rey NA, Pagnotta MA, 2016. Globe artichoke in vitro conservation protocol to meet germplasm preservation and production management. Acta Hortic. 1147:421-8.

Temirkaynak M, Adak N, Küçük S, Nama H, 2008. The Agronomic Performance of Seed Propagated Artichoke in Antalya-Turkey. Proc. IV-th Balkan Symp. on Vegetables and Potatoes, 9-12 September, Plovdiv, Bulgaria.

Temperini O, Calabrese N, Temperini A, Rouphael Y, Tesi R, Lenzi A, Colla G, 2013. Grafting artichoke onto cardoon rootstocks: Graft compatibility, yield and Verticillium wilt incidence. Sci. Hortic. 149:22-7.

Trinchera A, Pandozy G, Rinaldi S, Crinò P, Temperini O, Rea E, 2013. Graft union formation in artichoke grafting onto wild and cultivated cardoon: An anatomical study. J. Plant Physiol. 170:1569-78.

Welbaum GE, 1994. Annual culture of globe artichoke from seed in Virgina. HortTechnol. 4:147-9.

Virdis A, Motzo R, Giunta F, 2009. Key phenological events in globe artichoke (Cynara cardunculus var. scolymus) development. Ann. Appl. Biol. 155:419-29.

Virdis A, Motzo R, Giunta F, 2014. The phenology of seedpropagated globe artichoke. Ann. Appl. Biol. 164:128-37.

Wiebe HJ, 1989. Vernalisation von wichtigen Gemüsearten - Ein Überblick. Gartenbauwissenschaft 54:97-104.

Zeipina S, Alsina I, Lepse L, 2015. Influence of agroecological factors on artichoke yield and quality: Review. Res. Rural Dev. $1: 77-81$. 